\title{
Hepatoprotective effect of sesame oil against lead induced liver damage in albino mice: Histological and biochemical studies
}

\author{
Azab El-Saied Azab \\ Department of Zoology, Faculty of Science, Alejelat, Zawia University, Zawia, Libya \\ Email address: \\ azabelsaied@yahoo.com
}

\section{To cite this article:}

Azab El-Saied Azab. Hepatoprotective Effect of Sesame Oil against Lead Induced Liver Damage in Albino Mice: Histological and Biochemical Studies. American Journal of BioScience. Special Issue: Natural Products: Health and Disease. Vol. 2, No. 6-2, 2014 , pp. 1-11. doi: 10.11648/j.ajbio.s.2014020602.11

\begin{abstract}
The liver performs many vital functions to eliminate toxins and harmful substances from the body. Hepatotoxic agents can react with the basic cellular components and consequently induce almost all types of liver lesions. The aim of this study was to investigate the possible hepatoprotective role of sesame oil against lead acetate induced hepatotoxicity in albino mice from the histological and biochemical aspects. In this study, thirty two adult male albino mice were used for this study and divided into four groups. The first group was control group, the $2^{\text {nd }}$ was the sesame oil group orally received sesame oil $(5 \mathrm{ml} / \mathrm{kg}$ body wt.), the $3^{\text {rd }}$ group was the experimental and received lead acetate $(500 \mathrm{mg} / \mathrm{kg} \mathrm{diet})$, the $4^{\text {th }}$ one co-administered lead acetate $(500 \mathrm{mg} / \mathrm{kg}$ diet) with sesame oil $(5 \mathrm{ml} / \mathrm{kg}$ body wt.) daily for 30 days. The livers were dissected out, weighted and specimens were taken and processed for light microscopic examinations. Blood samples were obtained for assessment of serum alanine aminotransferase, aspartate aminotransferase, alkaline phosphatase and $\gamma$-glutamyltransferase activities, serum total proteins and albumin. Results indicate that, in lead treated animals, there were severe structural damage in the liver. The hepatocytes appeared irregularly arranged with disorganization of hepatic architecture. The hepatocytes appeared large with light and foamy cytoplasm filled with numerous vacuole-like spaces. The nuclei appeared with pyknotic nuclei. The central vein appeared dilated and congested with massive hemorrhage extending to the nearby cells. Also, there were focal degenerative and necrotic changes along with inflammatory cell infiltration. Decrease in body weight and increase in liver weight were observed. Biochemically, the serum alanine aminotransferase, aspartate aminotransferase, alkaline phosphatase, and $\gamma$-glutamyltransferase activities were increased and serum total proteins and albumin were decreased. Co-administration of sesame oil significantly improved the structural changes in the liver and also the serum alanine aminotransferase, aspartate aminotransferase, alkaline phosphatase and $\gamma$-glutamyltransferase activities were significantly declined and serum total proteins and albumin were elevated. Conclusion: It can be concluded that, the lead had adverse effects on the liver. Sesame oil showed effective hepatoprotective action against lead acetate induced hepatotoxicity in albino mice. So, the populations of high risk to lead should be advised to take sesame oil.
\end{abstract}

Keywords: Lead Acetate, Hepatotoxicity, Hepatoprotective, Serum Enzymes Activities (ALT, AST, ALP, $\gamma$-GT), Histology, Serum Total Proteins, Serum Albumin, Sesame Oil

\section{Introduction}

Liver plays a vital role in detoxification and excretion of many endogenous and exogenous substances [1]. Continuous exposure and intoxication of liver to different types of exogenous compounds on a daily basis may lead to hepatic dysfunction [2]. Hepatic dysfunction due to exposure to environmental toxic agents is increasing worldwide. Toxins and drugs are among the basic etiopathogenetic agents of acute liver failure in Western countries [3].

Lead is a poisonous metal, which exist in both organic and inorganic forms in the environment [4]. Lead poisoning is one of the oldest and the most widely studied occupational and environmental hazards [5]. The exposure to lead can occur from a multitude of sources such as soil, air, water and industrial pollutants. It has been used in medicines, paintings, pipes, ammunition and in more recent times in alloys for welding storage materials for chemical reagents [6]. There are worldwide, six categories of products considered as source of 
lead exposure, that is, gasoline additives, food cane soldering, lead based paints, ceramic glazes, drinking water systems, and folk remedies [7]. Autopsy studies of lead exposed humans indicate that liver tissue is the largest repository (33\%) of lead among the soft tissues followed by kidney cortex and medulla [8]. Several reports have indicated that lead can cause neurological, hematological, gastrointestinal, reproductive, circulatory and immunological pathologies, all of them related to the dose and the duration of time of lead exposure [9 \&10]. Toxicities due to lead exposure have been attributed to the ability of lead to induce oxidative stress through the generation of reactive oxygen species [11].

Nowadays, there is an increasing interest in discovering the protective biological function of natural compounds contained in dietary plants due to safe use, their antioxidative properties and their possible roles in intra and extracellular defense against oxygen radicals and lipid peroxides in response to oxidative stress [12]. The ability of lead to induce reactive oxygen species could be supported by the fact that lead induced toxicities were found to be mitigated by some chelating agents [13] and certain antioxidants such as vitamin C, E, green tea, pectin, flaxseed oil [14 \& 15], methionine, N-acetylcysteine, homocysteine and $\alpha$-lipoic acid [16]. Plant extracts and materials of animal origin were also observed to protect against lead induced toxicity in experimental animals. The abilities of these extracts to mitigate these toxicities were attributed to the antioxidant properties of principles contained in these extracts [11].

Sesame oil is derived from the plant species Sesamum indicum L, a herbaceous annual in the Pedaliaceae family [17]. It contains several antioxidants and chemo-preventive agents such as tocopherol [18], sesamolin, sesaminol [19] and sesamin [20]. They also contain a good type of monounsaturated and polyunsaturated fatty acids [21], highly nutritious, rich in vitamin $\mathrm{A}, \mathrm{B}$ and $\mathrm{E}$ as well as the minerals iron, calcium, magnesium and copper [22]. Sesame oil is incredibly popular for its nutritional antioxidant and medicinal properties [23]. It is well known for its multiple health benefits, including hypocholesterolemic, anti-hypertensive, anticarcinogenic, anti-aging, immuno- regulatory, hypoglycemic, antithrombotic, hepatoprotective [24, 25], anti-bacterial, antiviral, anti-fungal and anti-inflammatory [26].

Antioxidant potential of the sesame oil in the amelioration of metal induced oxidative stress need thorough investigation because these natural antioxidants are components of many edible substances and has the potential for safe future use by humans. The evidence reporting the protective effect of sesame oil against chronic lead toxicity in liver are hardly found. So, the present work aimed to evaluate effectiveness of sesame oil against the histological and also biochemical alterations of lead induced hepatotoxicity in albino mice.

\section{Materials and Methods}

\subsection{Chemicals}

Lead acetate and sesame oil were purchased from Sigma Chemical Co., USA.
Sesame oil was given orally by gavages at a volume of 5 $\mathrm{ml} / \mathrm{kg}$ body weight according to the previous study of Hussien et al. [27]

Lead acetate was given in diet as $500 \mathrm{mg} / \mathrm{kg}$ diet daily [4] for 30 days. The choice of the dose of sesame oil was based on the results of the previous studies, where the antioxidant effect of this agent was confirmed.

\subsection{Animals}

Thirty two adult male albino mice (Mus musculus) weighting 25-30 g were used for this study. The animals were obtained from animal house unit in the Faculty of Pharmacy, Tripoli University, Libya. The animals were housed in plastic cages measuring about $(29 \times 15 \times 12) \mathrm{cm}$, with about four mice per cage. Floors of cages were covered with soft crushed wood shaving; all cages were washed two times per week with $70 \%$ alcohol throughout the period of the study. The animals were provided with tape water ad libitum and fed with the standard commercial chow. The animals were kept in the animal house of Faculty of Science, Alejelat, Zawia University in an air conditioned room with an optimum temperature of $25 \pm 2{ }^{\circ} \mathrm{C}$, humidity (60-70\%) and light/dark condition (12/12). The animal procedures were performed in accordance with Guide Lines for Ethical Conduct in the Care and Use of Animals.

\subsection{Experimental Design}

After one week of acclimation, the animals were randomized and divided into four groups ( 8 albino mice for each) as follow:

Group I (control group): provided with tape water and fed with normal diet.

Group II (sesame oil group): The animals received sesame oil ( $5 \mathrm{ml} / \mathrm{kg}$ body $\mathrm{wt} /$ day) orally by gavage daily for 30 days.

Group III (lead acetate treated group): The animals received $500 \mathrm{mg}$ lead acetate/ $\mathrm{kg}$ diet daily for 30 days.

Group IV (lead acetate/sesame oil co-administered): The animals received $500 \mathrm{mg}$ lead acetate/ $\mathrm{kg}$ diet concurrently with sesame oil ( $5 \mathrm{ml} / \mathrm{kg}$ body wt/day) orally by gavage daily for 30 days.

At the end of the experimentation and 24 hours after the last dose, all animals were weighted and then sacrificed under light ether anesthesia, then rapidly dissected and subjected to the following examinations:

\subsection{Histological Examination}

The liver was exposed by mid line incision and then rapidly dissected from the surrounding structures and weighted. Liver specimens were obtained and fixed in buffered $10 \%$ formaldehyde solution for 24 hours and processed for paraffin sections of 5 micron thickness. The sections were stained with Hematoxylin and Eosin and examined under light microscopy [28].

\subsection{Biochemical Analysis}

Blood samples were drown by cardiac puncture and centrifuged at $3000 \mathrm{rpm}$ for 15 minutes to harvest the serum 
with which the liver functions assessment were analyzed. The activities of Alanine aminotransferase(ALT), aspartate aminotransferase (AST) were determined in serum according to the methods described by Reitman and Frankel [29]. Serum alkaline phosphatase (ALP) activity was determined according to Kind et al. [30]. Serum $\gamma$-GT activity was determined according to the method of Szas [31]. Serum total proteins concentration was determined according to Biuret method explained by Tietz [32]. Serum albumin concentration was determined according the method of Doumas et al. [33].

\subsection{Statistical Analysis}

The values were presented as means \pm SD of different groups. Differences between the mean values were estimated using one way ANOVA. The results were considered statistically significant when $\mathrm{p}<0.05$.

\section{Results}

Histologically, by light microscopic examination, the liver appeared with normal structure in all control groups (negative and positive control animals). The hepatocytes arranged in cell strands radiating from the central vein with intervening blood sinusoids which appeared to be lined by Kupffer cells. The hepatocytes appeared pentagonal and contained large nuclei. No detectable pathological changes showed in the liver of mice treated with sesame oil alone as well as the controls (Fig. 1).

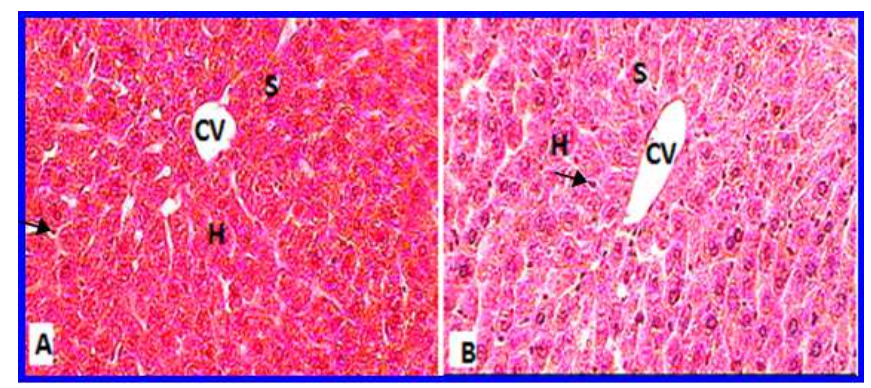

Fig. (1). Light micrograph of sections in the liver of control albino mice ; A: Negative control, B: Positive control (administered sesame oil only); Central vein (CV); Kupffer cells ((); Hepatocytes (H); Sinusoids (S). (Haematoxylin \& $\operatorname{Eosin} \times 400)$.

Lead acetate treated mice showed distortion of the arrangement of parenchyma of the liver, loss of radial arrangement of sinusoids from the central vein of the liver. Marked necrosis of hepatocytes, that appeared deeply esinophilic, and some with pyknotic nuclei (Fig. 2A, B \& C) when compared with the control (Fig. 1A). The hepatocytes appeared large with light and foamy cytoplasm filled with numerous vacuole-like spaces. Many hepatic cells were damaged and lost their characteristic appearance. Others showed severe cytoplasmic vacuolation (Fig. 3B) which is so extensive in some cells to the extent that only slight remnants of the cytoplasmic mass were left. Hyper activation of Kupffer cells were observed (Fig. 2A). There were severe diltations and congestions of centeral veins, sinus and portal blood vessels (Fig. 2). Some areas showed multifocal to diffuse type of coagulative necrosis. Most of the portal veins appeared congested with inflammatory cells infiltrations (Fig. 3A). Marked vacuolar degeneration mainly hydropic degeneration (Fig. 3B). The bile ducts were seen enlarged and hyperplasic (Fig. 2D).

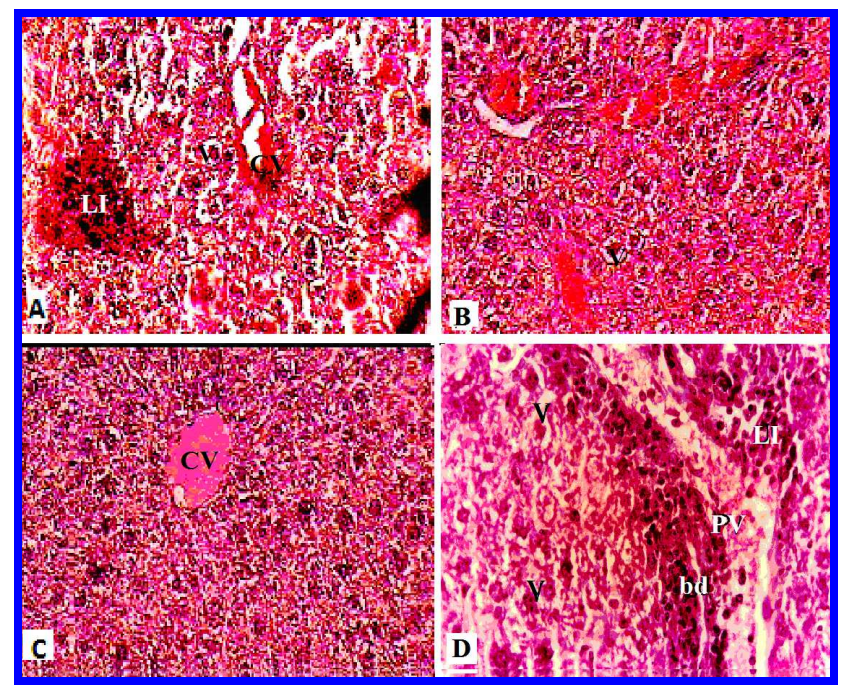

Fig. (2). Light micrograph of sections in the liver of lead treated group presenting; A: wide spread necrobiotic changes in the hepatocytes, dilatation of blood sinusoid lumen, and marked vacuolar degeneration (V) mainly hydropic degeneration. $B \& C$ : Distortion of the arrangement of parenchyma of the liver, loss of radial arrangement of sinusoids from the central vein of the liver and loss of hexagonal shape of the hepatocytes. Dilatation and congestion of central veins $(\mathrm{CV})$, sinus and portal veins. Marked necrosis of hepatocytes, that appeared deeply esinophilic, and some with pyknotic nuclei. D: Marked vacuolar degeneration of hepatocytes mainly hydropic degeneration $(V)$, congested and dilated portal vein $(P V)$, inflammatory cells infiltration (LI), hyperplasic bile duct (bd), (Haematoxylin \& Eosin $\times 400$ ).

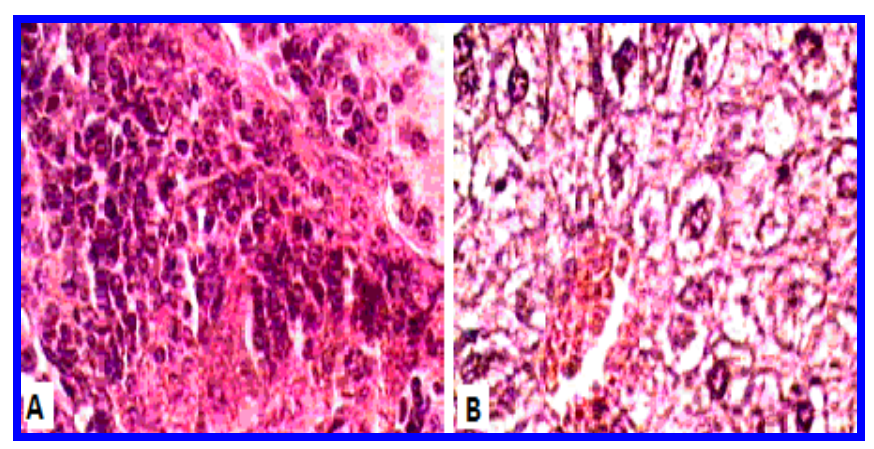

Fig. (3). Light micrograph of sections of a higher magnification in the liver of lead acetate treated albino mice. A: Marked inflammatory cells infiltration B: Marked vacuolar degeneration mainly hydropic degeneration, the central vein appeared congested with massive hemorrhage extending to the nearby cells. These necrotic cells appeared homogenous structurless with degenerated nuclei. (Haematoxylin \& Eosin $\times 1000$ ).

The liver of lead acetate treated albino mice co-administered sesame oil showed marked improvement in its histological structure in comparison to the group treated with lead acetate alone. the central vein appear more or less normal. The liver sections showed the hepatocytes regained their normal organization and architecture (Fig. 4).

Tables 1, 2 showed the means and standard deviations for 
serum ALT, AST, ALP, and $\gamma$ - GT activities in control groups, lead acetate treated group and albino mice group co-administrated of lead acetate with sesame oil. The levels of serum alanine aminotransferase (ALT), aspartate aminotransferase (AST), alkaline phosphatase (ALP), and $\gamma$ glutamyltransferase $(\gamma-\mathrm{GT})$ activities were elevated in lead acetate treated animals compared with the control groups with statistically significant differences $(p<0.05)$. The enzyme activities in the co-administration of lead acetate with sesame oil were decreased with statistically significant differences $(\mathrm{p}<0.05)$ (Figs. 5, 6, $7 \& 8$ ), when compared with lead acetate group.

Table (1). Effect of sesame oil on the serum alanine aminotransferase, and aspartate aminotransferase activities of lead acetate treated male albino mice in different groups.

\begin{tabular}{lll}
\hline \multirow{2}{*}{ Groups } & ALT $(\mathbf{U} / \mathbf{L})$ & AST $(U / L)$ \\
\cline { 2 - 3 } & Mean \pm SD & Mean \pm SD \\
\hline Control & $29.6 \pm 1.67$ & $51.23 \pm 3.12$ \\
Sesame oil & $27.4 \pm 1.01$ & $48.61 \pm 1.31$ \\
Lead acetate & $47.2 \pm 3.50 \mathrm{a}$ & $76.45 \pm 4.18 \mathrm{a}$ \\
Lead acetate + Sesame oil & $31.22 \pm 1.35 \mathrm{~b}$ & $55.51 \pm 2.46 \mathrm{~b}$ \\
\hline
\end{tabular}

a : Significant differences as compared with control group $(\mathrm{P}<0.05)$.

${ }^{\mathrm{b}}$ : Significant differences as compared with lead acetate treated group ( $\mathrm{P}<$ $0.05)$. All data are mean of 8 individuals.

Table (2). Effect of sesame oil on the serum alkaline phosphatase, and $V$ glutamyltransferase activities of lead acetate treated male albino mice in different groups.

\begin{tabular}{lll}
\hline \multirow{2}{*}{ Groups } & ALP (U/L) & V-GT (U/L) \\
\cline { 2 - 3 } & Mean \pm SD & Mean \pm SD \\
\hline Control & $44.19 \pm 2.05$ & $8.54 \pm 0.41$ \\
Sesame oil & $46.01 \pm 1.06$ & $9.16 \pm 0.33$ \\
Lead acetate & $72.12 \pm 3.98^{\mathrm{a}}$ & $13.31 \pm 0.82^{\mathrm{a}}$ \\
Lead acetate + Sesame oil & $49.13 \pm 3.27^{\mathrm{b}}$ & $9.62 \pm 0.39^{\mathrm{b}}$ \\
\hline
\end{tabular}

a : Significant differences as compared with control group $(\mathrm{P}<0.05)$.

b : Significant differences as compared with lead acetate treated group ( $\mathrm{P}<$ $0.05)$. All data are mean of 8 individuals.

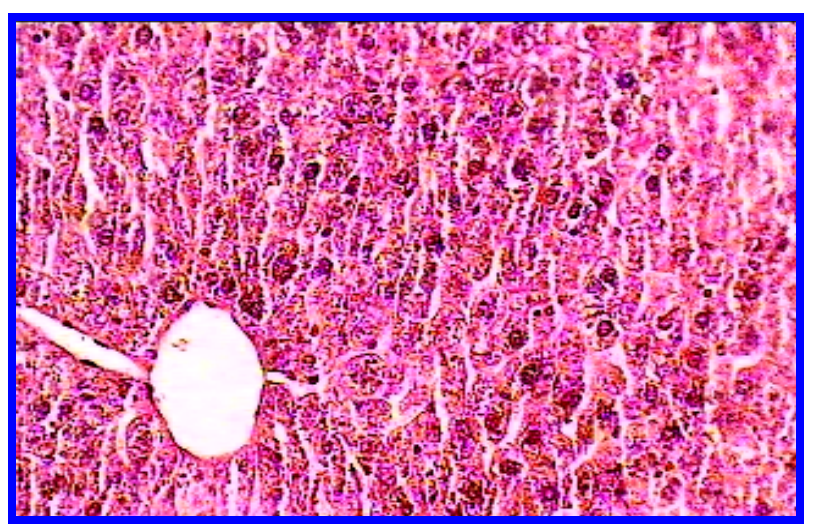

Fig. (4). Light micrograph of a sections in the liver of lead acetate treated albino mice co-administered sesame oil. The central vein appear normal. The hepatocytes regained their normal organization and architecture. (Haematoxylin \& Eosin $\times 400$ ).

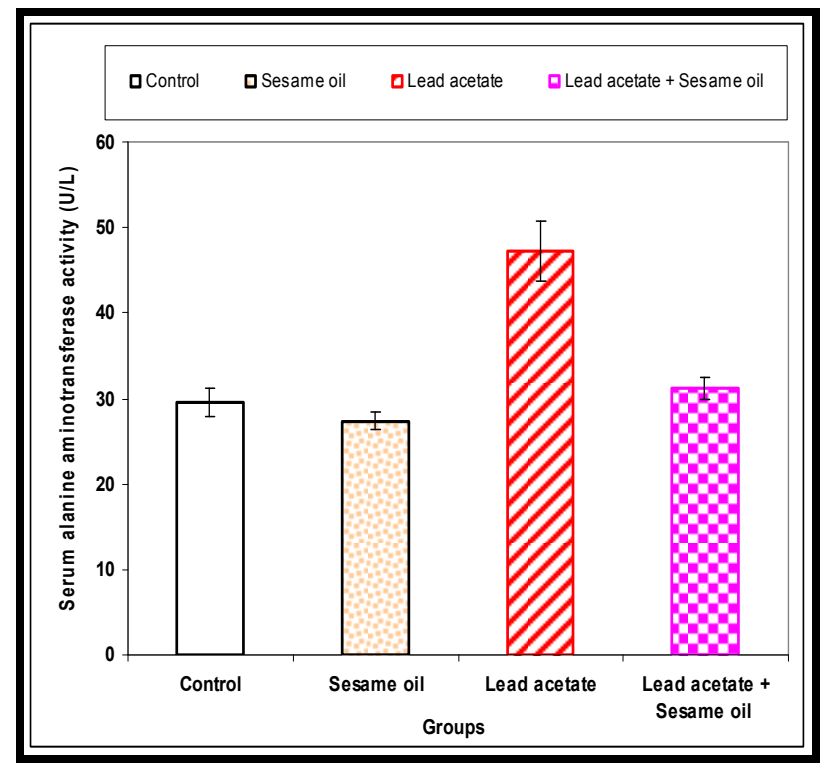

Fig. (5). The serum alanine aminotransferase (ALT) activity in different animals groups. The serum ALT activity is the highest in lead acetate treated group in comparison with control groups (normal control and sesame oil treated).The serum ALT activity shows declining in co-administered lead acetate and sesame oil treated.

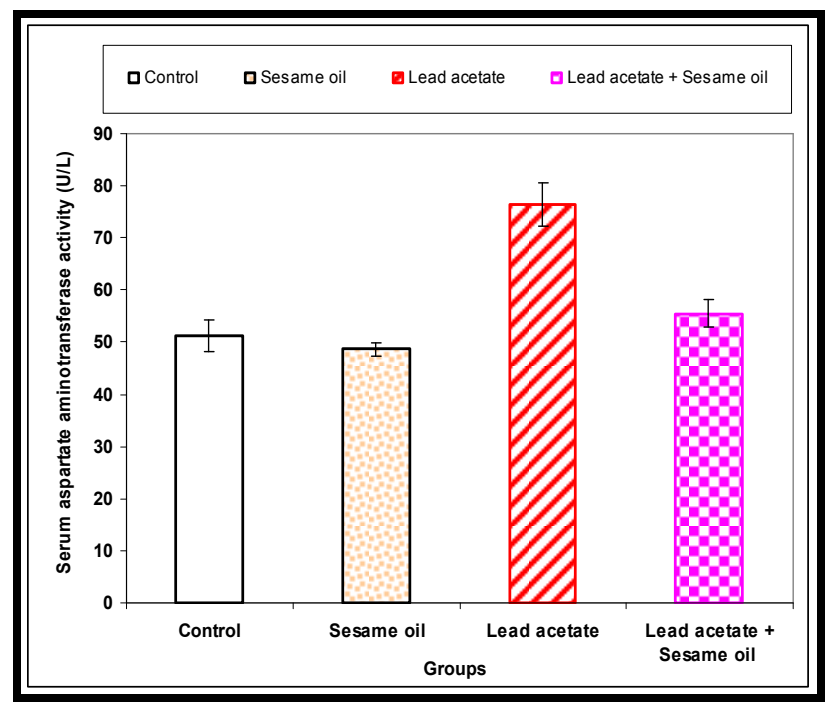

Fig. (6). The serum aspartate aminotransferase(AST) activity in different animals groups. The serum AST activity is the highest in lead acetate treated group in comparison with control groups (normal control and sesame oil treated).The serum AST activity shows declining in co-administered lead acetate and sesame oil treated.

Table (3) displays the serum total proteins and albumin concentration of control groups and experimental animals groups. The levels of serum total proteins and albumin concentrations were declined in lead acetate treated animals compared with the control groups with statistically significant differences $(\mathrm{p}<0.05)$. The levels of serum total proteins and albumin concentrations in the co-administration of lead acetate with sesame oil were increased with statistically significant differences $(p<0.05)$ (Figs. 9 \& 10), when compared with lead acetate group.

Regarding the changes in body and relative liver weight of 
the animals in the present study, the body weight at the end of the experiment decreased in the lead acetate treated animals compared with the control groups with statistically significant differences $(p<0.05)$. The weight increased in co-administered lead acetate and sesame oil with significant differences $(\mathrm{p}<0.05)$ from the lead acetate treated group. The relative liver weight increased in lead acetate treated group as compared with the control group with statistically significant differences $(p<0.05)$. The relative liver weight decreased in co-administered lead acetate and sesame oil with significant differences (Table 4 and Figs 11 \& 12), when compared with lead acetate group.

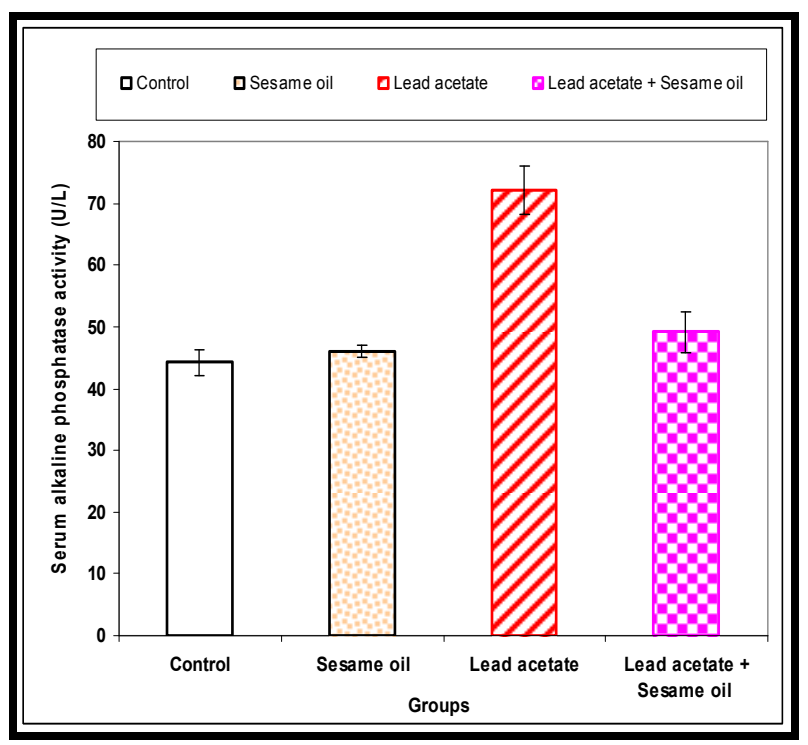

Fig. (7). The serum alkaline phosphatase activity (ALP) in different animals groups. The serum ALP activity is the highest in lead acetate treated group in comparison with control groups (normal control and sesame oil treated). The serum ALP activity shows declining in co-administered lead acetate and sesame oil treated.

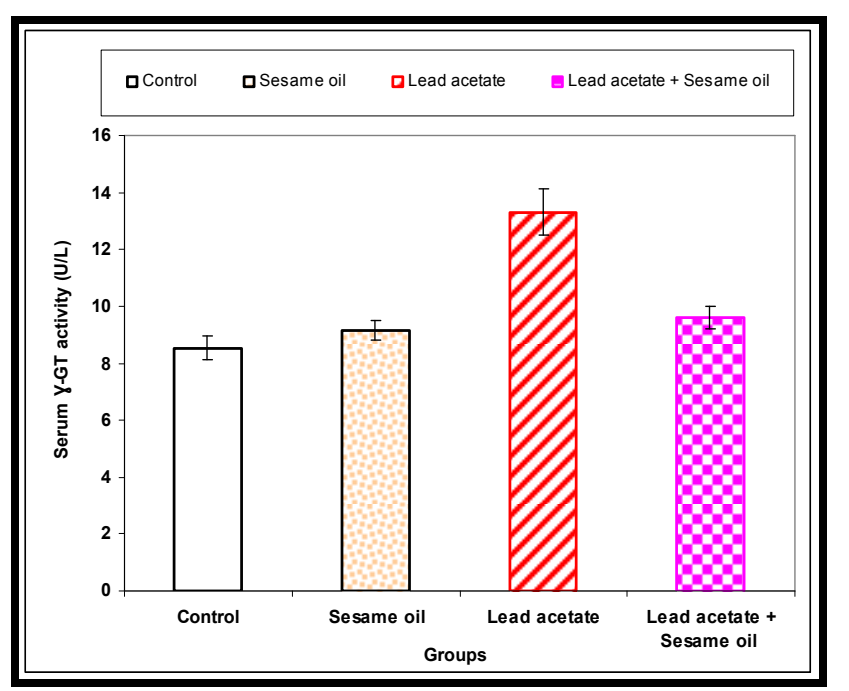

Fig. (8). The serum $\gamma$-glutamyltransferase $(\gamma-G T)$ activity in different animals groups. The serum $\gamma$ - glutamyltransferase activity is the highest in lead acetate treated group in comparison with control groups (normal control and sesame oil treated). The serum $\gamma$-glutamyltransferase activity shows declining in co-administered lead acetate and sesame oil treated.
Table (3). Effect of sesame oil on total proteins and albumin in the serum of lead acetate treated male albino mice in different groups.

\begin{tabular}{lcc}
\hline \multirow{2}{*}{ Groups } & Total proteins $(\mathbf{g} / \mathbf{d l})$ & Albumin $(\mathbf{g} / \mathbf{d l})$ \\
\cline { 2 - 3 } & Mean \pm SD & Mean \pm SD \\
\hline Control & $6.67 \pm 0.29$ & $4.19 \pm 0.22$ \\
Sesame oil & $6.86 \pm 0.25$ & $4.30 \pm 0.0 .13$ \\
Lead acetate & $4.55 \pm 0.32^{\mathrm{a}}$ & $2.99 \pm 0.17^{\mathrm{a}}$ \\
Lead acetate + & $6.63 \pm 0.24^{\mathrm{b}}$ & $4.01 \pm 0.19^{\mathrm{b}}$ \\
Sesame oil & \\
\hline
\end{tabular}

a : Significant differences as compared with control group $(\mathrm{P}<0.05)$.

b : Significant differences as compared with lead acetate treated group ( $\mathrm{P}<$ 0.05). All data are mean of 8 individuals.

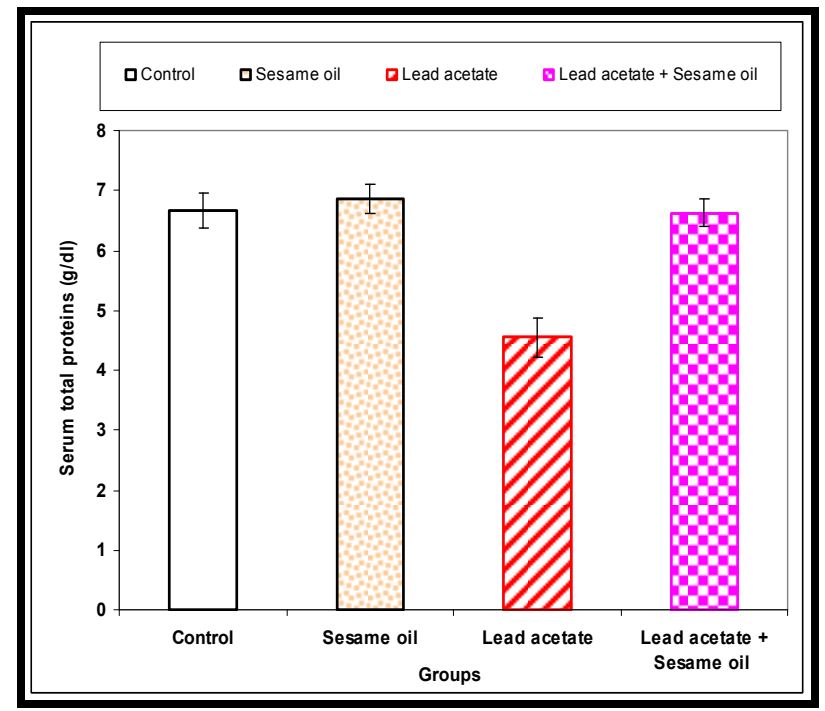

Fig. (9). The serum total proteins concentration in different animals groups. The serum total proteins concentration is markedly declined in lead acetate treated group in comparison with control groups (normal control and sesame oil treated). The serum total proteins concentration shows declining in co-administered lead acetate and sesame oil.

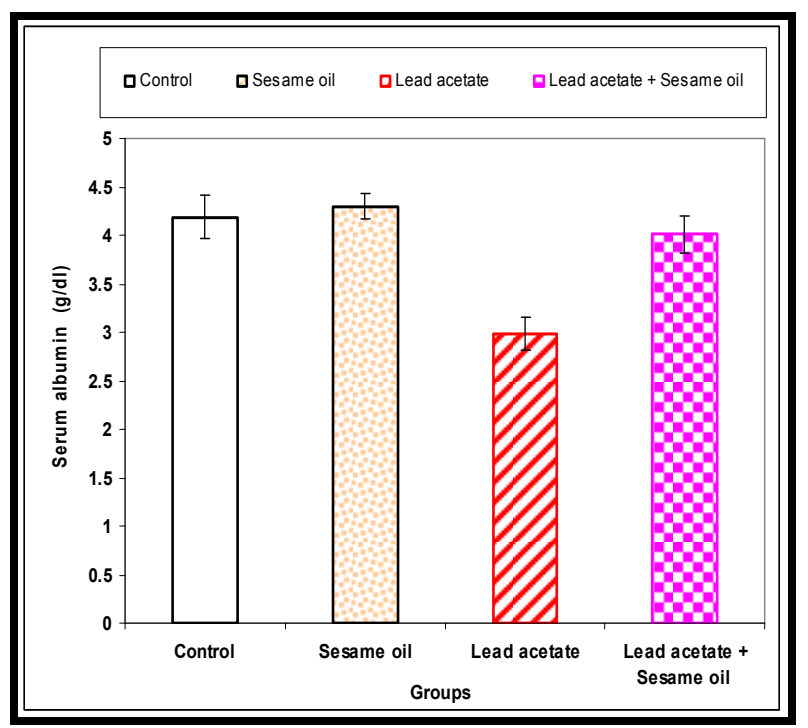

Fig. (10). The serum albumin concentration in different animals groups. The serum albumin concentration is markedly declined in lead acetate treated group in comparison with control groups (normal control and sesame oil treated). The serum albumin concentration shows declining in co-administered lead acetate and sesame oil. 
Table (4). Effect of sesame oil on body weight and relative liver weight of lead acetate treated male albino mice in different groups.

\begin{tabular}{lll}
\hline \multirow{2}{*}{ Groups } & $\begin{array}{c}\text { Body weight } \\
(\mathbf{g})\end{array}$ & $\begin{array}{c}\text { Relative liver weight } \\
\text { (gm/100 gm of body weight) }\end{array}$ \\
\cline { 2 - 3 } & Mean \pm SD & Mean \pm SD \\
\hline Control & $32.5 \pm 1.21$ & $4.25 \pm 0.33$ \\
Sesame oil & $31.3 \pm 1.03$ & $4.11 \pm 0.15$ \\
Lead acetate & $26.00 \pm 1.5^{\mathrm{a}}$ & $5.77 \pm 0.30^{\mathrm{a}}$ \\
Lead acetate + Sesame oil & $30.2 \pm 1.35^{\mathrm{b}}$ & $4.31 \pm 0.21^{\mathrm{b}}$ \\
\hline
\end{tabular}

${ }^{a}$ : Significant differences as compared with control group $(\mathrm{P}<0.05)$.

${ }^{\text {b }}$ : Significant differences as compared with lead acetate treated group $(\mathrm{P}<$ 0.05). All data are mean of 8 individuals.

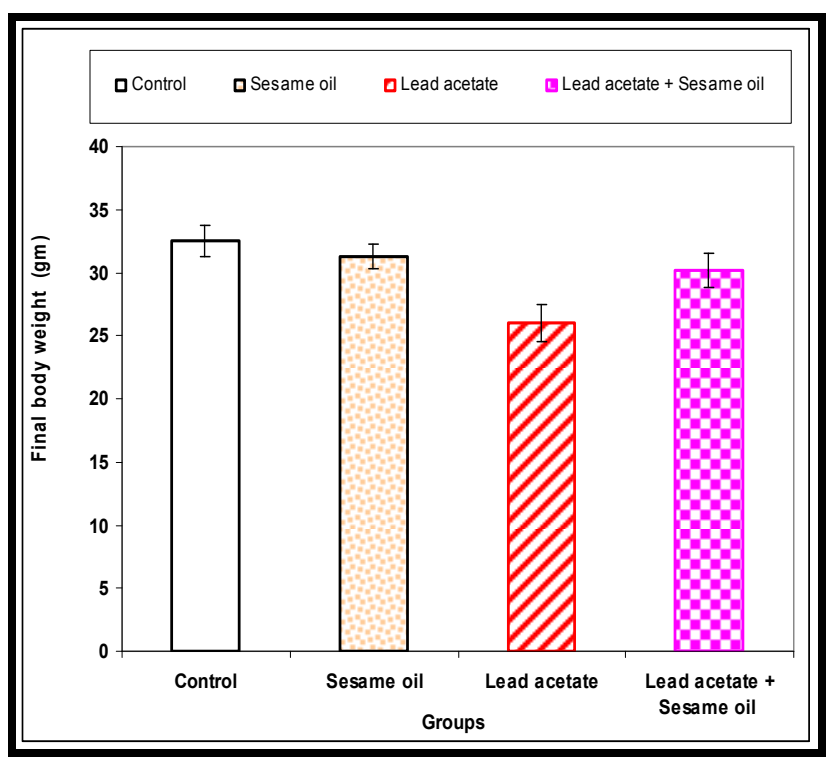

Fig. (11). The body weight in different animals groups. The body weight decreased in lead acetate treated group in comparison with control groups (normal control and sesame oil treated). The body weight increases in co-administered lead acetate and sesame oil.

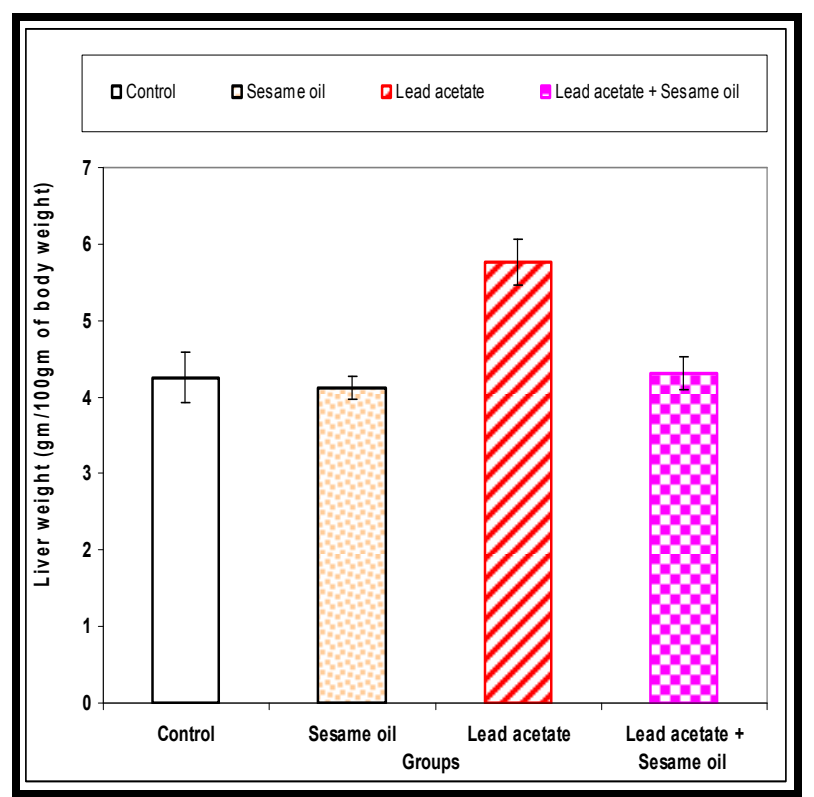

Fig. (12). The liver weight in different animals groups. The liver weight increases in lead acetate treated group in comparison with control groups (normal control and sesame oil treated). The weight declines in co-administered lead acetate and sesame oil.

\section{Discussion}

In this study, the lead acetate had adverse effects on the liver. Histologically, the hepatocytes appeared irregularly arranged with disorganization of hepatic architecture. The hepatocytes appeared large with light and foamy cytoplasm filled with numerous vacuole-like spaces. The nuclei appeared pyknotic nuclei. The central vein appeared dilated and congested with massive hemorrhage extending to the nearby cells. Also, there were focal degenerative and necrotic changes along with inflammatory cell infiltration. This is in agreement with many authors who reported the toxicity of lead on the liver $[4,8$, 34-36]. Similar observations were reported by Suradkar et al. [37] who found that lead acetate can cause lesion characterized by engorgement of blood vessels along with sinusoidal hemorrhages, perivascular mononuclear cell infiltration, dilatation of central veins, vacuolar degeneration of hepatocytes and increased cytoplasmic eosinophilic granularity, swelling of hepatocytes with the variable degree of nuclear changes, distortion of hepatic chords and areas of diffused vacuolar and granular degeneration. Lead exposure produced pronounced hepatic histopathology evidenced by histological alternations in liver including focal necrosis with inflammatory cells, congestion at places, sinusoids not patent, centre lobular swelling, hepatocyte vacuolization and swelling, parenchyma disorganization, dilation of the inter hepatocyte space, and hemorrhagic clots [35]. Abd El Kader et al. [34] found that the lead can cause severe hepatocytes damage, dilation of blood sinusoids and loss of architecture were seen after acute treatment for 7 days. The appearance of inflammatory cells in the hepatic tissue, due to lead chronic exposure, may suggest that lead could interact with proteins and enzymes of the hepatic interstitial tissue interfering with the antioxidant defense mechanism and leading to reactive oxygen species generation which in turn may imitate an inflammatory response [38].

Cell necrosis and vacuolization induced by lead toxicity as shown in the present work were described previously by other studies [39 \& 40]. Robbins and Angell [41] regarded such vacuolation to represent primary morphologic response to many forms of cell injury. They also attributed it to the noxious effects of treatment on the cell membranes, both structurally and functionally, causing marked disturbances in its permeability system. This presumably leads to enhanced imbibition of water into the cells. When it sufficiently accumulates in the cells, such intracellular water produced clear cytoplasmic vacuoles indication the occurrence of the pathologic symptoms commonly referred to as hydropic degeneration or fatty degeneration caused by lipid abundance in such instance.

The patho-morphological lesions in liver may be due to the action of lead on hepatic glycogen, DNA content and the ability to incorporate amino acid into protein [42]. Mechanisms of lead-induced liver injury include increased production of reactive oxygen species, and induced oxidative stress which results in DNA damage [43]. These reactive species interfere with cellular macromolecules and deactivates 
cellular antioxidant pool [44]. Many heavy metals, including lead, are known to induce over production of Reactive Oxygen Species and consequently enhance lipid peroxidation [45], decrease the saturated fatty acids and increase the unsaturated fatty acid contents of membranes [46], which become a hindrance in membrane transport [47].

In this work, treatment of albino mice with lead acetate caused a significant increase of the activities of serum AST, ALT, ALP and $\gamma$-GT. Similar observations were reported in many experimental investigations on animals exposed to lead [46 \& 48]. In addition, Shalan et al. [4] has reported that serum ALT, AST, ALP and GGT activities were elevated in rats treated with lead acetate as early as the end of the second week of treatment and ALT was elevated significantly more than AST on lead exposure. The increase in such enzymes might be due to increased cell membrane permeability [49], or damage of hepatocytes caused by lead acetate [50]. Treatments with lead acetate were found to cause a significant increases in serum ALT, AST and ALP activities [51 \&52]. Attia et al. [53] reported increased activities of ALT and AST in rats during lead poisoning. Increasing levels of AST and ALT in the plasma of treated rats is mainly due to the leakage of these enzymes from the liver cytosol into the blood stream [54]. Releasing of AST and ALT from the cell cytosol can occur as secondary changes to cellular necrosis [55]. Furthermore, Ibrahim et al. [55] reported that the high plasma AST and ALT activities are accompanied by high liver microsomal membrane fluidity, free radical generation and alteration in the liver tissue.

The present study, revealed that treatment of albino mice with lead acetate induced a significant decrease in the values of serum levels of total proteins, and albumin. Similar findings coincided by Ibrahim et al. [46]. The level of total proteins was decreased in rats treated with lead [4, $46 \& 48]$. The decrease in serum total proteins may be due to both hepatic and renal damage induced by lead [56], or may be due to binding of lead to some metal binding proteins and their removal through detoxification processes [57], where it causes alteration in a high number of enzymes and can also disturb protein synthesis in hepatocytes [58]. Moreover, the decreasing of serum total proteins values may be attributed to a decrease in hepatic DNA and RNA induced by lead intoxication or due to decreased utilization of free amino acids for protein synthesis [4]. The DNA damage by lead may be due to depletion of antioxidant enzymes [59]. Moreover, El-Zayat et al. [60] found that a decrease in hepatic total proteins content in response to lead intoxication. They attributed that to a decreased utilization of free amino acids for protein synthesis. Also, the observed decrease in the total proteins and albumin in the liver could be attributed to the damaging effect of lead acetate on liver cells as confirmed by increasing in the activities of serum AST and ALT after treatment of rats with lead acetate [61\& 62]. Hypoproteinemia is reflecting liver injury [63], which may be due to significant fall in protein synthesis [64].

From the obtained results, the weight of the animals exposed to lead acetate were significantly decreased. The present results are in accordance with other studies which found that exposure of rats to lead acetate causes a decrease in body weight gain [36, $46 \& 65]$. Decreased body weight was previously observed by Allouche et al. [65] who administered $0.1 \%$ lead acetate to male rats during 11 months. Moreover, The decrease in body weight is not only a consequence of decreased food consumption $[17,24,54]$, but also from direct toxicity of the lead acetate, perhaps by the interruption in absorption, and metabolism of feed nutrients essential for health [66], from toxic effects on the gastrointestinal tract or by inhibition of protein synthesis [67]. The decreased body weight explained by Kaltreider et al. [68] who found that exposure to low level of heavy metals impairs the glucocorticoid system. The glucocorticoid hormones play a vital role in glucose regulation as well as carbohydrate, lipid and protein metabolism. Dysfunction in the glucocorticoid system has been linked to weight gain loss.

This study shows that, the relative liver weight increased at the end of the experiment in lead acetate treated group. This is in agreement with many authors who reported the toxicity of lead on the liver weight [36]. Prabu et al. [69] who found that oral administration of cadmium chloride as a heavy metal resulted in increase of the relative liver weight. Also, the liver weight increased in cadmium treated male rats, and mice [70].

Co-administration of sesame oil with lead acetate significantly regained their normal organization and architecture of the hepatocytes, and the central vein appeared normal. Similarly, pretreatment of rats with two different doses $(400 \mathrm{mg} / \mathrm{kg}$ and $700 \mathrm{mg} / \mathrm{kg})$ of Sesamum indicum for 21 days before administration paracetamol produced a significant reduction of paracetamol-induced elevation of serum enzymes markers and reduced histopathological scores of fatty degeneration, centre lobular necrosis with significant evidence of regeneration. The results of the study indicate that the extract of Sesamum indicum possesses significant protection against Paracetamol-induced hepatocellular injury [71].

Also, Prasanthi et al. [22] found that the liver of rats fed dietary sesame oil and Fenvalerate showed normal histology suggesting marked protection afforded by sesame oil. The mechanism by which dietary sesame oil attenuates the oxidative damage is not clear, it is speculated that the antioxidant components (sesamol and sesamolinol and sesaminol) present may be largely responsible for this protective response.

This study revealed that administration of sesame oil along with lead acetate, showed a good protective effect by restoration of biochemical profiles in the hepatic functional indicators in serum. This was also well correlated with normal histological architecture in the liver. This is in agreement with Uthandi and Ramasamy [72] who found that the elevation in ALT, AST, ALP activities and reduction total proteins level significantly restored towards normalization by sesame meal treatment in high fat fed Wistar rats. Also, the activities of hepatic ALT, AST and ALP in rats fed dietary sesame oil and Fenvalerate were significantly modulated suggesting varying degree of protection [22]. Sesame normalized the elevated levels of Serum glutamate oxaloacetate transaminase, serum 
glutamate pyruvate transaminase, alkaline phosphatase, total proteins, and albumin [73]. Levels of ALT and AST increased with co-exposure to lead and lipopolysaccharide induced liver injury but were lower with sesamin treatment, suggesting that sesamin may protect rats from lead and lipopolysaccharide liver injury [74 \& 75]. Sesamin could protect from liver injury by attenuating the increased serum IL-1, IL-6, TNF-a and nitrite in the lead induced rats [76].

Sesame oil ameliorated the reduction in plasma total proteins and albumin induced by cypermethrin. The protective effect of sesame oil against the toxicity of cypermethrin may be related to its antioxidant effect and its ability to inhibit the lipid peroxidation [27].

Co-administration of sesame oil with lead acetate to albino mice significantly improves the body and liver weights. This in agreement with Hussien et al. [27] who demonstrated that treatment with sesame oil ameliorated the alteration in body weight induced by cypermethrin, which may be attributed to the vital role of sesame oil as antioxidant. The antioxidant activity of sesame oil could be attributed to its phenolic lignans type compounds namely sesamol, sesamin and sesaminol [76]. The liver weights were significantly reduced in rats fed dietary sesame oil and Fenvalerate when compared to rats fed dietary Fenvalerate [22].

Sesame oil have been shown to possess free radical scavenging properties and protect oxidative stress induced toxic injuries. Many researchers investigated the role of sesame oil in the attenuation of hepatic injury. Chiang et al. [75] have shown that sesamin effectively ameliorated lead and lipopolysaccharide-induced acute liver injury in rats by the inhibition of proinflammatory cytokines and nitric oxide. They further pointed out that the inhibition of liver injury is through the suppression of several signaling pathways, such as c-Jun N-terminal kinase, p38 mitogen-activated protein kinase, cyclooxygenase-2, inducible nitric oxide synthase, and growth arrest DNA damage $45 \mathrm{~b}$. It seems that sesamin can mitigate the hepatic injury through these gateways. The authors found that the effect of sesamin was through the suppression of several signaling pathways. The interaction and real role of these pathways in relation to the effect of sesamin are unknown. Hsu et al. [77] reported that sesame oil attenuates cisplatin induced hepatic and renal injuries by inhibiting nitric oxide associated lipid peroxidation in mice. Erol et al. [78] found that, sesame oil treatment has a potent protective effect against apoptosis induced by cyclosporine- $\mathrm{A}$ in rats, as revealed by remarkable decrease in apoptotic cells in the liver. The mechanisms underlying hepatoprotection of sesame oil may be related to both their radical scavenging properties and indirect effects as a regulator of antioxidative systems. Sesamin has been reported to protect against alcohol and chemical-induced liver injury. It is speculated that the mechanism underlying hepatoprotection of sesamin is via suppression of the free radical- mediated process triggered by hepatotoxins [24]. Furthermore, Chaudrasekaran et al. [79] stated that sesame oil enhanced the antioxidant status and inhibited lipid peroxidation in rats with acetaminophen induced acute liver injury. These findings indicate that sesame oil is a potent antioxidant rich oil as it possesses some preventive substances such as sesamin, sesaminol and sesamolin besides its wealth with fat soluble vitamins like tocopherol [18]. Sesame oil was found to protect against oxidative stress and hepatic injury after cecal ligation and puncture in rats, which may be attributable to the antioxidant components in sesame oil [20 \& 80].

\section{Conclusion}

From the previous discussion, it can be concluded that, the lead had adverse effects on the liver. Sesame oil showed effective hepatoprotective action against lead acetate induced hepatotoxicity in albino mice. So, the populations of high risk to lead should be advised to take sesame oil. Further studies are necessary to elucidate exact mechanism of protection of hepatotoxicity and potential usefulness of sesame oil as a protective agent against heavy metals toxicity in clinical trials.

\section{References}

[1] Buraimoh AA, Bako IG and Ibrahim FB: Hepato- protective effect of ethanolic leaves extract of Moringa Oleifera on the histology of paracetamol induced liver damage in wistar rats. Int. J Anim Vet Adv 2011;3(1): 10-13.

[2] Nithya N, Chandrakumar K, Ganevan V and Senthilkumar S: Efficacy of Momordica charantia in attenuating abnormalities in cyclophosphomide intoxicated rats. J Pharmacol Toxicol 2012, 7(1): 38-45.

[3] Grattagliano I, Bonfrate L, Catia VD, Wang HH, Wang DQH and Portincasa P: Biochemical mechanisms in drug-induced liver injury. World J Gastroenterol 2009;5: 4865-4876.

[4] Shalan MG, Mostafa MS, Hassouna MM, Hassab El-Nabi SE and El-Refaie A : Amelioration of lead toxicity on rat liver with Vitamin C and silymarin supplements. Toxicol 2005; 206: 1-15.

[5] Flora SJS, Flora G and Saxena G: Environmental occurrence, health effects and management of lead poisoning. In: Jose SC and Jose S, editors. Lead. Amsterdam. Elsevier Sci 2006: 158-228.

[6] Garaza A, Vega R and Soto E: Cellular mechanisms of lead neurotoxicity. Med Sci Monitor 2006;12(3): 57-65.

[7] Markowitz M: Lead poisoning. Pediatrics Rev 2000; 21(10): 327-335.

[8] Mudipalli A : Lead hepatotoxicity and potential health effects. Indian J Med Res 2007;126: 518-527.

[9] Park SK, Schwartz J, Weisskopf M, Sparrow D, Vokonas PS, Wright RO, Coull B, Nie H and Hu H: Low level lead exposure, metabolic syndrome, and heart rate variability: The VA Normative Aging Study. Environ Health Perspect 2006;114: 1718-1724.

[10] Ademuyiwa O, Ugbaja RN, Rotimi SO, Abam E, Okediran BS, Dosumu OA and Onunkwor BO: Erythrocyte acetyl-cholinesterase activity as a surrogate indicator of lead-induced neurotoxicity in occupational lead exposure in Abeokuta, Nigeria. Environ Toxicol Pharm 2007;24:183-188. 
[11] Adikwu E, Deo O, Geoffrey, OBP and Enimeya DA: Lead organ and tissue toxicity: Roles of mitigating agents (Part 1). British J Pharm Toxicol 2013;4(6): 232-240.

[12] Marzook EA, Abd El Moneim AE and Elhadary AA: Protective role of sesame oil against mobile base station-induced oxidative stress. J Ra d Res Appl Sci 2014; 7 : $1-6$.

[13] Jackie T, Haleagrahara $\mathrm{N}$ and Chakravarthi S: Antioxidant effects of Etlingera elatior flower extract against lead acetate induced perturbations in free radical scavenging enzymes and lipid peroxidation in rats. BMC Research Notes 2011; 4:67-75.

[14] Patra, R.C and Swarup D: Effects of antioxidant ascorbic acid, l-methionine and $\alpha$-tocopherol alone or along with chelator on cardiac tissue of lead- treated rats. Vetrinarski Arhiv 2004;74: 235-244.

[15] Abdel-Moneim AE, Dkhil MA and Al-Quraishy S: The potential role of flaxseed oil on lead acetate induced kidney injure in adult male albino rats. African J Biotechnol 2011;10: 1436-1451.

[16] Upadhyay AK, Mathur R, Bhadauria M and Nirala SK: Therapeutic influence of zinc and ascorbic acid against lead induced biochemical alterations. Therapie 2009; 64(6):383-388.

[17] Sugano M and Akimoto KA: Multifunctional gift from nature. J Chin Nutr Soc 1993; 18: 1-11.

[18] Fukuda Y: Food chemical studies on the antioxidants in sesame seed. Nippon Shokuhin Kogyo Gakkaishi 1990;37: 484- 492.

[19] Kang MH, Katsuzaki $H$ and Osawa $\mathrm{T}$ : Inhibition of 2,20-azobist (2,4-dimethyl-valeronitrile) induced lipid peroxidation by sesaminols. Lipid 1998; 33: 1031-1036.

[20] Chavali SR, Utsunomiya, T and Forse, RA: Increased survival after cecal ligation and puncture in mice consuming diets enriched with sesame oil. Crit Care Med 2001;29: 140-143.

[21] Choi AM, Lee SB, Cho SH, Hwang I, Hur CG and Suh MC: Isolation and characterization of multiple abundant lipid transfer protein isoforms in developing sesame (Sesamum indicum ) seeds. Plant Physiol Biochem 2008;46(2): 127-139.

[22] Prasanthi K, Muralidhara A and Rajini, PS: Fenvalerate induced oxidative damage in rat tissues and its attenuation by dietary sesame oil. Food Chem Toxicol 2005;43(2): 299-306.

[23] Isha D and Milind P: Eat til and protect dil. IRJP 2012; 3 (11): 54-57.

[24] Namiki M: Nutraceutical functions of sesame: a review. Crit Rev Food Sci Nutr 2007; 47:651-673.

[25] Huang, YS: Open, sesame! The gateway to mitigate hepatic injury using sesamin. J Chinese Med Asso 2014;77: 219-220.

[26] Kandangath RA, Ajay P, Farhath $\mathrm{K}$ and Amarinder SB: Nutritional, medicinal and Industrial uses of sesame (Sesamum indicum L.) seeds - An Overview. Agricult Consp Sci 2010;75(4):159-168.

[27] Hussien HM, Abdoub HM and Yousef MI: Cypermethrin induced damage in genomic DNA and histopathological changes in brain and haematotoxicity in rats: The protective effect of sesame oil. Brain Res Bull 2013;92: 76- 83.

[28] Ross MH, Reith EJ and Romrell LJ: Histology, A Text Atlas (2nd ed.) Baltimore. Williams \&Wilkins ,1989, pp.51- 84.

[29] Reitman S and Frankel A: Colorimetric method for determination of serum glutamate oxaloaectate and glutamic pyruvate transaminase. Amer J Clin Pathol 1957; 28: 56-58.

[30] Kind PRN, King EJ, Varley H, Gowenlock AH and Bell M: Method of practical clinical biochemistry. Heinman, London, 1980, pp. 899-900.

[31] Szas G: Reaction rate method for gamma glutamyl transferase activity in serum. Clin Chem 1976;22: 2031-2055.

[32] Tietz NW: Biuret method for the determination of total protein in serum. In: Fundamental of clinical chemistry. WBS Saunders Co. Philadelphia, Toronto, London, U.K.,1976, P: $503 \& 879$.

[33] Doumas BT, Watson WA and Homer CB: Albumin standard and measurement of the albumin with bromocresol green. Clin Chem Acta 1971;31: 87-96.

[34] Abd El Kader MA, El-Sammad NM and Taha H: The Protective Role of Rosemary (Rosmarinus officinalis) in Lead Acetate Induced Toxicity in Rats. J Appl Sci Res 2012;8(6): 3071-3082.

[35] Mannem P: Protective effects of ginger extract against lead induced hepatotoxicity in male albino rats . IOSR-J Environ Sci Toxicol Food Technol 2014;8(5): 53-59.

[36] El Sokkary GH, Abdel-Rahman GH and Kamel ES: Melatonin protects against lead induced hepatic and renal toxicity in male rats. Toxicol 2005; 231: 25-33.

[37] Suradkar SG, Vihol PD, Patel JH, Ghodasara DJ, Joshi BP and Prajapati KS: Patho-morphological changes in tissues of Wistar rats by exposure of lead acetate. Veter World 2010;3: 82-84.

[38] Johar D, Roth JC, Bay GH, Walker JN, Kroczak TJ and Los M: Inflammatory response, reactive oxygen species, programmed (necrotic-like and apoptotic) cell death and cancer. Rocz Akad Med Bialymst 2004;49: 31-39.

[39] Nehru B and Kaushal S: Alterations in the hepatic enzymes following experimental lead poisoning. Biol Trace Elem Res 1993;38: $27-34$

[40] Jarrar BM and Taib NT: Histological and histochemical alterations in the liver induced by lead chronic toxicity. Saudi J Biol Sci 2012;19: 203-210.

[41] Robbins SL and Angell M: Basic Pathology.2nd ed. W.B. Saunders Company, Phildelphia, London, 1976.

[42] Barrat CLR, Davies AG and Bansal MR: The effects of lead on the male rat reproductive system. Androl 1989;21:161-166.

[43] Xu J, Lian LJ, Wu C, Wang XF and Fu WY: Lead induces oxidative stress, DNA damage and alteration of $\mathrm{p} 53$, Bax and Bcl-2 expressions in mice. Food Chem Toxicol 2008;46: 1488-1494.

[44] Flora SJS, Gautam P and Dwivedi N: Dose dependent effects of ethanol on lead induced oxidative stress in rats. J. Environ. Path. Toxicol. Oncol. 2012;31: 61-73.

[45] Chaurasia SS and Kar A : Protective effects of vitamin E against lead induced deterioration of membrane associated type-1 iodothyronine 5-monodeiodinase (5D-I) activity in male mice. Toxicol 1997;124:203-209. 
[46] Ibrahim NM, Eweis EA, El-Beltagi HS and Abdel Mobdy YE: Effect of lead acetate toxicity on experimental male albino rat. Asian Pac J Trop Biomed 2012;2: 41-46.

[47] Pratap M and Indira P: Protective effects of ginger (Zingiber officinale) extract Against lead induced oxidative stress on liver Antioxidant enzymes in male albino rats. Int $\mathrm{J}$ pharm Bio Sci 2014 ; 5 (2) : 888-894.

[48] Azoz HA and Raafat RM : Effect of lead toxicity on cytogenisity, biochemical constituents and tissue residue with protective role of activated charcoal and casein in male rats. Australian J Bas Appl Sci 2012; 6(7): 497-509.

[49] Rubin EI: In Essential pathology, 3rd edition, Lippincott Williams \& Wilkins, Wolters Kluver Company USA, 1995.

[50] Tatjana J, Gordana K, Dusica P and Ivana S: Effects of captopril on membrane associated enzymes in lead induced hepatotoxicity in rats. Acta Fac Med Naiss 2003; 20: 183-188.

[51] Haleagrahara N, Jackie T, Chakravarthi S, Rao M and Anupama K: Protective effect of Etlingera elatior (torch ginger) extract on lead acetate induced hepatotoxicity in rats. J Toxicol Sci 2010; 35: 663-671.

[52] Baxla SL, Gora RH, Kerketta P, Kumar N, Roy BK and Patra PH: Hepatoprotective effect of Curcuma longa against lead induced toxicity in Wistar rats. Vet World 2013;6(9): 664-667.

[53] Attia AMM, Ibrahim FAA, Nabil GM and Aziz SW: Antioxidant effects of ginger (Zingiber officinale Roscoe) against lead acetate-induced hepatotoxicity in rats. Afr J Pharm Pharmacol 2013;7(20): 1213-1219.

[54] Concepcion NM, Pilar MM, Martín A, Jiménez J and Pilar UM: Free radical scavenger and anti-hepatotoxic activity of Rosmarinus tomentosus.. Planta Med 1993;59: 312-314.

[55] Gaskill CL, Miller LM and Mattoon JS: Liver histopathology and liver and serum alanine aminotransferase and alkaline phosphatase activities in epileptic dogs receiving phenobarbital Veter Pathol 2005;42(2):147-160.

[56] Ahmed YF and Shalaby SIA: Clinco-pathological and histopathological studies on chronic lead intoxicated in male Bakri sheep. Afric J Agri Sci 1999; 18: 19-37.

[57] Yousef MI: Aluminum-induced changes in haematobiochemical parameters, lipid peroxidation and enzyme activities of male rabbits: Protective role of ascorbic acid. Toxicol 2004;199(1): 47-57.

[58] Georing PL: Lead - protein interactions as a basis for lead toxicity. Neur Toxicol 1993;14: 45-60.

[59] Salma K and Kshama D: Effect of Withania somnifera root extract on lead - induced DNA damage. J Food Agricul Environ 2005;3(1): 31-33.

[60] El-Zayat EM, El-Ymany NA and Kamel ZH: Combined supplementation of zinc and Vitamin $\mathrm{C}$ as protective agents against lead toxicity in growing male albino rats. 1. Liver functions. J. Egypt Ger. Soc. Zool. 1996;20(A): 115-139.

[61] Abdou HM and Hassan MA: Protective role of omega-3 polyunsaturated fatty acid against lead acetate-induced toxicity in liver and kidney of female rats. BioMed Res Inter 2014; Article ID 435857, 11 pages.

[62] Abdou HM and Newairy AA: Hepatic and reproductive toxicity of lead in female rats and attenuation by flaxseed
Lignans. J Med Res Inst 2006;27: 295-302.

[63] Akilavalli N, Radhika J and Brindha P: Hepatoprotective activity of Ocimum sanctum against lead induced toxicity in albino rats. Asian J Pharm Clin Res 2011; 4(2): 84-87.

[64] Dubey GP, Agrawal A and Dixit SP: Effect of Liv-52 on different biochemical parameters in alcoholic cirrhosis. Antiseptic 1994; 91:205-208.

[65] Allouche L, Hamadouche M, Touabti A and Khennouf S: Effect of long-term exposure to low or moderate lead concentrations on growth, lipid profile and liver function in albino rats. Adv Biol Res 2011;5: 339-347.

[66] Marchlewicz M, Wiszniewska B, Gonet B, Baranowska BI, Safranow K, Kolasa A, Glabowski W, Kurzawa R, Jakubowska $\mathrm{K}$ and Rac ME: Increased lipid peroxidation and ascorbic acid utilization in testis and epididymis of mice chronically exposed to lead. Biometals 2006 pp.13.

[67] Hammond PB, Minnema DJ and Shulka R: Lead exposure lowers the set point for food consumption and growth in weanling rats. Toxicol Appl Pharm 1990;106: 80-87.

[68] Kaltreider RC, Davis AM, Lariviere JP, and Hamilton JW: Arsenic alters the function of the glucocorticoid receptor as a transcription factor. Environ Health Perspect 2001;109: 245-251.

[69] Prabu MS, Muthumani M and Shagirtha K: Protective effect of piper betle leaf extract against cadmium-induced oxidative stress and hepatic dysfunction in rats. Saudi J Biol Sci 2012;19: 229-239.

[70] Yamano T, Shimizu M and Noda T: Comparative effects of repeated administration of cadmium on kidney, spleen, thymus, and bone marrow in 2-, 4-, and 8-month-old male Wistar rats. Toxicol Sci 1998;46: 393-402.

[71] Munish K, Sisodia SS, Anjoo K and Vaibhava R: Evaluation of hepatoprotective effect of Sesamum indicum Linn. seed extract against paracetamol induced hepatotoxicity in Rats. Inter $\mathrm{J}$ Pharm and Clin Res 2011;3(3): 66-69

[72] Uthandi A and Ramasamy K: Hepatoprotective activity of sesame meal on high fat fed wistar rats. Inter J Pharm Sci and Res 2011;2(12):205-211.

[73] Gauthaman K and Saleem MTS: Nutraceutical value of sesame oil. Pharmacol Rev 2009; 3(6): 264-269.

[74] Hsu DZ, Chen KT, Chu PY, Li YH and Liu MY: Sesame oil protects against lead plus lipopolysaccharide induced acute hepatic injury. Shock 2007; 27(3):334-337.

[75] Chiang HM, Chang H, Yao PW, Chen YS, Jeng KC, Wang JS and Hou CW: Sesamin reduces acute hepatic injury induced by lead coupled with lipopolysaccharide. J Chin Med Assoc 2014;77: 227-233.

[76] Suja KP, Jayalekshmy A and Arumughan C: Free radical scavenging behavior of antioxidant compounds of sesame (Sesamum indicum L.) in DPPH system, J Agric Food Chem 2004; 52: 912-915.

[77] Hsu DZ, Chen KT, Lin TH, Li YH and Liu MY: Sesame oil attenuates cisplatin induced hepatic and renal injuries by inhibiting nitric oxide-associated lipid peroxidation in mice. Shock 2007; 27: 199-204. 
[78] Erol AYG, Bulbul A, Avcı G, Ozdemir M and Akkaya O: the protective effects of omega-3 fatty acids and sesame oil on cyclosporine-A induced liver apoptosis. JAREM 2011; 1: 8-11.

[79] Chaudrasekaran VRM, Wan CH, Liu LL, Hus DZ and Liu, M: Effect of sesame oil against acetaminophen induced acute oxidative hepatic damage in rats. Shock 2008; 30(2):217-221.
[80] Hsu DZ, Li YH, Chien SP and Liu MY: Effects of sesame oil on oxidative stress and hepatic injury after cecal ligation and puncture in rats. Shock 2004; 21: 466-469. 